\title{
MATERI PENDIDIKAN AGAMA ISLAM DALAM KERANGKA TEORI SOSIAL (THEORIES: GRAND, MIDDLE, AND GROUNDED)
}

\author{
Arham Junaidi Firman \\ UIN Sunan Kalijaga Yogyakarta, Email: arhamjf@yahoo.com
}

\begin{abstract}
ABSTRAK
Kajian ini dilakukan karena praktik pendidikan agama Islam tidak cukup dilakukan dengan cara diakronis saja. Perlu ada pendekatan metodologis yang baru, yaitu dengan pendekatan multidisipliner, yaitu penggabungan beberapa disiplin untuk bersama-sama mengatasi masalah-masalah tertentu, seperti pemecahan masalah dalam pendidikan agama Islam dengan menggunakan teori-teori sosial. Memperbincangkan pendidikan agama Islam dalam kerangka teori sosial bisa diibaratkan dengan pohon yang baik, yaitu memiliki akar kuat, batang yang kokoh, daun rimbun dan buah yang manis karena mendapatkan perawatan terbaik. Pendidikan agama Islam dalam kerangka teori sosial mencakup tiga ranah, yaitu grand theory, middle theory dan grounded theory. Membicarakan pendidikan agama Islam dalam ranah grand theory, maka yang menjadi kajiannya adalah 'Aqīdah, Akhlāk, Al-Quran-Hadis, Fiqh dan Tarikh. Sedangkan, membicarakan pendidikan agama Islam dalam ranah middle theory, maka kajian yang dikembangkan mencakup lima grand theory tersebut, seperti grand theory Akhlāk dengan middle theory, yaitu hablum minallāh, hablum minannās dan hablum ma'al gairi. Sementara itu, jika membicarakan pendidikan agama Islam dalam ranah grounded theory, maka kajian yang dikembangkan didasarkan kepada grand dan middle tehory, yaitu akhlāk mậmūdah dan mażmumah.
\end{abstract}

Kata Kunci: Multidisipliner; Materi Pendidikan Agama Islam; Teori Sosial

\begin{abstract}
This study was carried out because the practice of Islamic religious education was not enough to be carried out in a diachronic way only. There needs to be a new methodological approach, namely a multidisciplinary approach, which is the merging of several disciplines to jointly overcome certain problems, such as solving problems in Islamic religious education withusing social theories. Discussing Islamic religious education in terms of social theory can be compared to a good tree, which has strong roots, sturdy stems, lush leaves and sweet fruit because it gets the best care. Islamic religious education within the framework of social theory includes three domains, namely grand theory, middle theory and grounded theory. Discuss Islamic religious education in the realm of grand theory, then the study is the Aqeedah, Morals, Al-Quran-Hadith, Fiqh and Date. While, discussing Islamic religious education in the realm of middle theory, the study developed includes five grand theories, such as the grand theory of morality with middle theory, namely hablum minallāh, hablum minannās and hablum ma'alghairi. Meanwhile, when discussing Islamic religious education in the realm of grounded theory, the study developed is based on the grand and middle tehory, namely the morals of mahmüdah and mazmumah.
\end{abstract}

Keywords: Multidisciplinar; Islamic Religious Education Material; Social Theory

\section{PENDAHULUAN}

Realitas sebuah perubahan yang merupakan suatu hukum alam dan juga merupakan "realitas keagungan Tuhan" harus disikapi secara flexibility. Perubahan yang terus bergulir akan mengubah paradigma memandang dunia penuh keteraturan menjadi dunia penuh tantangan untuk mencapai ketenangan. Hal ini diindikasikan dengan berubahnya fase newtonian menjadi fase quantum dan economical capital 
menjadi intellectual capital. Perubahan-perubahan ini juga akan berimbas pada realitas konsumtif menuju realitas reinventor bahkan juga membangun realitas kompetitif-regional menjadi realitas kompetitif-global (Tabrani, 2014: 212).

Perubahan tersebut akan membawa rancangan mekanisme atau aturan tersendiri yang akan menjadi suatu sistem nilai-nilai (systems of values) "luhur" dan juga menjadi pegangan setiap individu, keluarga, atau kelompok komunitas atau masyarakat tertentu, atau pada gilirannya bangsa dan negara tertentu. Hal ini pernah disinyalir oleh John Naisbitt dan Patricia Aburdence, futurolog suami istri terkemuka dunia, pada era dekade tahun 90an yang meramalkan bahwa abad 21 merupakan era baru (Tholkhah, 2004). Ternyata ramalan dua futurolog dunia tersebut menjadi "kebenaran tak terbantahkan" bahwa perubahan realitas/era telah menjadi era dengan nilai baru. Suatu era di mana yang menjadi bagian global dalam kehidupan manusia adalah fenomena ekonomi global dan informasi. Bahkan, pola relasi menggantikan hirarki sebagai modal utama untuk menyelesaikan semua problema kehidupan.

Dunia pendidikan, khususnya pendidikan agama Islam tidak akan lepas dari unsur perubahan. Karena hal tersebut tidak lepas dari hukum alam yang akan merongrong pendidikan agama Islam untuk menapak tangga yang lebih tinggi dan juga tuntutan untuk menempatkan eksistensinya sesuai dengan tuntutan realitas. Akan tetapi, walaupun dalam realitas tersebut terus mengalir perubahan-perubahan yang menuntut hal lain pada dunia pendidikan agama Islam dan juga pada manusia, namun curiosity harus tetap menjadi spirit dalam hidup manusia (Mas'ud, 2002).

Pendidikan agama Islam mempunyai sejarah yang panjang sejak dari pendidikan informal sampai kepada pendidikan formal dan non-formal dalam masyarakat agraris maupun industri. Artinya, rentang waktu yang dilalui oleh pendidikan agama Islam sebagai bagian dari sejarah sosial kemanusiaan mempunyai hubungan erat dengan peradaban manusia itu sendiri dan juga rentang waktu perjalanan manusia di muka bumi. Sejarah pendidikan agama Islam selama ini masih menggunakan pendekatan konvensional-diakronis dengan karakteristik; (1) kajiannya berpusat pada sejarah dari ide-ide dan tokoh pemikir besar, (2) sejarah dan sistem pendidikan serta lembaga-lembaga, (3) sejarah perundang-undangan dan kebijakan umum dalam bidang pendidikan agama Islam. Pendekatan yang umumnya bersifat diakronis ini dianggap statis, sempit serta terlalu melihat ke dalam. Seiring dengan perkembangan zaman dan kemajuan dalam pendidikan beserta segala macam masalah yang timbul atau ditimbulkannya, penanganan serta pendekatan baru dalam pendidikan agama Islam dirasakan sebagai kebutuhan yang mendesak pada saat ini (Tabrani, 2014).

Sehubungan dengan hal di atas, maka pendekatan dalam praktik pendidikan agama Islam tidak cukup dengan cara-cara diakronis saja. Perlu ada pendekatan metodologis yang baru, yaitu dengan pendekatan multidisipliner. Dalam pendekatan 
multidisipliner dilakukan penggabungan beberapa disiplin untuk bersama-sama mengatasi masalah-masalah tertentu, seperti pemecahan masalah dalam pendidikan agama Islam dengan menggunakan teori-teori sosial yang mempelajari tentang perilaku manusia dalam berinteraksi.

Memperbincangkan pendidikan agama Islam dalam kerangka teori sosial bisa diibaratkan dengan pohon yang baik, yaitu memiliki akar kuat, batang yang kokoh, daun rimbun dan buah yang manis karena mendapatkan perawatan terbaik. Akar yang kuat sebagai teori sosial, batang yang kokoh sebagai grand theory, daun rimbun dan buah yang manis sebagai middle theory, perawatan yang baik sebagai grounded theory. Oleh karena itu, artikel ini mengungkap dan mengkaji lebih mendalam bagaimana materi pendidikan agama Islam dalam kerangka teori sosial.

\section{PEMBAHASAN}

Salah satu bagian yang patut mendapat perhatian ketika berbicara tentang pendidikan agama Islam adalah masalah kurikulum. Kurikulum dalam definisi Undang-Undang Sistem Pendidikan Nasional nomor 2 tahun 2003 adalah seperangkat rencana dan pengaturan mengenai tujuan, isi, dan bahan pelajaran serta cara apa digunakan sebagai pedoman penyelenggaraan kegiatan pembelajaran untuk mencapai tujuan pendidikan tertentu. Menurut Muhaimin sebagaimana yang dikutip Mahmudi (2019), dari definisi tersebut dijelaskan bahwa salah satu komponen penting dalam kurikulum adalah isi atau bahan pelajaran yang harus dikembangkan dari berbagai perspektif keilmuan atau dikenal dengan istilah multidisipliner.

Memperbincangkan materi pendidikan agama Islam dalam kerangka teori sosial ini sangatlah penting untuk diterapkan dalam dunia pendidikan sebagai paradigma keilmuan multidisipliner. Hal ini dikarenakan multidisipliner memberi ruang khusus bagi manusia sebagai makhluk yang dikaruniai akal pikiran untuk berilmu pengetahuan. Paham multidisipliner merupakan pendekatan dalam pemecahan masalah dengan menggunakan tinjauan berbagai sudut pandang ilmu, meskipun tidak serumpun (Rohmatika, 2019). Selain itu, multidisipliner dalam materi pendidikan agama Islam itu sendiri maupun keilmuan lain menunjukkan adanya keterpaduan/keintegralan antara pelajaran yang satu dengan pelajaran yang lain, dalam artian praktiknya harus terpadu ke luar dan ke dalam. Ke luar dalam artian bahwa praktik pendidikan agama Islam harus ada keterpaduan dengan praktik pembelajaran yang lain. Ke dalam maksudnya adalah ruang lingkup pendidikan agama Islam harus memiliki keterpaduan materi dalam praktiknya, sehingga kompetensi yang ingin dicapai oleh peserta didik menjadi utuh dan akan berdampak dengan tercapainya tujuan pendidikan.

Paham multidisipliner yang bermakna ke dalam disiplin ilmu itu sendiri maupun keilmuan lain diniatkan untuk menjadikan analisis keilmuannya secara utuh, menyeluruh dan totalitas (Assegaf, 2019). Sebagai contoh multidisipliner yang 
bermakna ke dalam disiplin ilmu itu sendiri dalam materi pendidikan agama Islam adalah pembahasan tentang akhlāk. Kajian ini tidak hanya dapat dipelajari dari sudut pandang pelajaran 'Aqīdah-Akhlāk, akan tetapi juga dapat dipelajari dari sudut pandang Al-Quran, Hadis, Fiqh dan juga Sejarah Kebudayaan Islam (SKI).

Sementara itu, kajian akhlāk melalui keilmuan lain dapat dilakukan secara multidisipliner dalam perspektif kerangka teori sosial sebagaimana yang telah disinggung pada poin sebelumnya. Materi pendidikan agama Islam dalam kerangka teori sosial menunjukkan bahwa; Pertama, dalam ranah grand theory, maka yang menjadi kajiannya adalah 'Aqīdah, Akhlāk, Al-Quran-Hadis, Fiqh dan Tarikh. Kedua, dalam ranah middle theory, maka kajian yang dikembangkan mencakup lima grand theory tersebut, seperti grand theory Akhlāk dengan middle theory-nya adalah hablum minallāh, hablum minannās dan hablum ma'al gairi. Ketiga, dalam ranah grounded theory, maka kajian yang dikembangkan didasarkan kepada grand dan middle tehory, yaitu akhlāk mahmmūdah dan mażmumah.

Oleh karena itu, dapat dipahami bahwa paham multidisipliner dalam materi pendidikan agama Islam dapat dipandang sebagai paham lanjutan dari integrasi ilmu. Sehingga penerapan paham multidisipliner ini dalam praktik pendidikan agama Islam sangatlah penting dan mendesak dengan perkembangan zaman dan kemajuan dalam pendidikan beserta segala macam masalah yang ditimbulkannya sebagaimana yang telah disinggung pada poin sebelumnya.

\section{Materi Pendidikan Agama Islam dalam Ranah Grand Theory}

Materi pelajaran adalah bahan ajar yang berada dalam ruang lingkup isi kurikulum. Bahan ajar adalah segala bentuk bahan yang digunakan untuk membantu pengajar/tutor dalam melaksanakan kegiatan belajar mengajar. Bahan yang dimaksud dapat berupa bahan tertulis ataupun bahan tidak tertulis yang memungkinkan anak didik dapat mempelajari dan menguasai suatu kompetensi. Sebuah bahan ajar paling tidak mencakup; (1) petunjuk belajar (petunjuk bagi pengajar/anak didik), (2) kompetensi yang akan dicapai, (3) informasi pendukung, (4) latihan-latihan, (5) petunjuk kerja, (6) evaluasi (Majid: 2005). Sementara itu, grand theory pada umumnya adalah teori-teori makro yang mendasari berbagai teori di bawahnya. Selain itu, disebut grand theory karena teori tersebut menjadi dasar lahirnya teori-teori lain dalam berbagai level. Grand theory disebut juga sebagai teori makro karena teori-teori ini berada di level makro, berbicara tentang struktur dan tidak berbicara fenomena-fenomena mikro (Subadi, 2009).

Telaah terhadap literatur di atas dalam hemat penulis menunjukkan bahwa grand theory materi pendidikan agama Islam merupakan kajian atau topik utama yang akan diberikan kepada peserta didik melalui pendidikan di sekolah, madrasah dan masyarakat. Sehingga grand theory dalam kaitannya dengan materi pendidikan agama Islam sebagai sebuah pendekatan multidisipliner memberikan implikasi 
bahwa yang menjadi kajian makro atau rung lingkup bahasannya adalah kajian nan, Ibadah, Al-Quran, Akhlāk, Muamalah, Syari'ah, dan Tarikh/sejarah (Muntholi'ah, 2002). Sementara itu, dalam Peraturan Menteri Agama No. 000912 Tahun 2013 dijelaskan bahwa yang menjadi grand theory materi pendidikan agama Islam, yatu; Al-Quran-Hadis, 'Aqīdah, Akhlāk, Fiqh dan Tarikh. Pengklasifikasian ini didasarkan kepada ruang lingkup pembahasan atau objek kajian Pendidikan Agama Islam yang tidak bisa dilepaskan dari grand theory tersebut.

1. Al-Quran-Hadits, merupakan sumber utama ajaran Islam, dalam arti keduanya merupakan sumber 'aqīdah, akhlāk, fiqh, sehingga kajiannya berada di setiap unsur tersebut.

2. 'Aqīiah, merupakan merupakan akar atau pokok agama. Syariah/fiqh (ibadah, muamalah) dan akhlāk bertolak dari 'aqīdah, yakni sebagai manifestasi dan konsekuensi dari keimanan dan keyakinan hidup.

3. Akhlāk, merupakan aspek sikap hidup atau kepribadian hidup manusia, yang mengatur hubungan manusia dengan Allah, hubungan manusia dengan manusia lainnya dan hubungan manusia dengan lingkungan sekitarnya.

4. Fiqh, merupakan sistem atau seperangkat aturan yang mengatur hubungan manusia dengan Allah (hablum minallāh), sesama manusia (hablum minan nas) dan dengan makhluk lainnya (hablum ma'al gairi).

5. Tarikh, merupakan catatan perkembangan perjalanan hidup manusia muslim dari masa ke masa dalam beribadah, bermuamalah dan berakhlāk serta dalam mengembangkan sistem kehidupan atau menyebarkan ajaran Islam yang dilandasi oleh 'aqīdah.

\section{Materi Pendidikan Agama Islam dalam Ranah Middle Theory}

Middle theory adalah di mana teori tersebut berada pada level mezzo atau level menengah yang fokus kajiannya makro dan juga mikro. Middle theory dikemukakan oleh sosiolog Amerika yang bernama Robert Merton dalam "Social Theory and Social Structure" pada tahun 1957 untuk menghubungkan pemisah di antara hipotesis-hipotesis terbatas dari studi empirisme dan teori-teori besar yang abstrak. Dia menjelaskan bahwa middle theory sebagai teori yang berbohong diantara minor-minor tapi diperlukan hipotesis yang berkembang dalam keadaan yang berlimpah dalam penelitian selama berhari-hari. Sehingga diperlukan usaha-usaha sistematis untuk mengembangkan teori gabungan yang akan menjelaskan seluruh penelitian yang seragam dari perilaku sosial, organisasi dan perubahan sosial. Banyak konsep yang dikembangkan dari middle theory telah menjadi bagian dari kosakata dasar sosiologi: retreatisme, ritualisme, manifest dan latent functions, opportunity structure, paradigm, reference group, role-sets, self-fulfilling propechy dan unintended concequence. Pemikiran middle theory secara langsung maupun tidak langsung mempengaruhi pandangan sosiolog atas pekerjaan mereka (Smith, 2008). 
Middle theory disepakati sebagai suatu bidang yang relatif luas dari suatu fenomena, tapi tidak membahas keseluruhan fenomena dan sangat memperhatikan kedisiplinan. Beberapa mid-range theories didasari oleh grand theory. Hal ini ditegaskan bahwa fungsi utama grand theory adalah sebagai sumber utama yang selanjutnya akan dikembangkan oleh middle theory (Kenna, 1997). Telaah literatur di atas, maka middle theory materi Pendidikan Agama Islam yang dikembangkan mencakup lima grand theory yang telah dibahas pada poin sebelumnya. Namun, dalam penulisan artikel ini, middle theory yang dikembangkan sebagai sebuah pendekatan multidisipliner hanya mengembangkan satu grand theory Akhlāk. Adapun middle theory dari grand theory Akhlāk adalah hubungan manusia dengan Allah (hablum minallāh), hubungan manusia dengan sesama manusia (hablum minannās) dan hubungan manusia dengan makhluk lainnya (hablum ma'al gairi). Manusia merupakan bagian dari alam semesta (kosmos) yang telah diciptakan oleh Allah sebagai abdi-Nya. Manusia diberikan kuasa oleh Tuhan untuk memanfaatkan, mengolah, dan menjaga potensi alam semesta yang telah diciptakan-Nya (khalifatullah). Dengan alam pula manusia berproses dan memperoleh pengetahuan dari Tuhan. Oleh karena itu, membahas hubungan antara manusia, alam, dan Allah sebagai pencipta tidak dapat dipisahkan (Samidi, 2016).

1. Hubungan manusia dengan Allah (Hablum Minallāh)

Al-Quran meletakkan kedudukan manusia sebagai khalīfah Allah di bumi sebagaimana firman-Nya dalam Q.S. Al-Baqarah ayat 30. Esensi makna khalīfah Allah adalah orang yang diberi amanah untuk memelihara dan memanfaatkan alam guna mendatangkan kemaslahatan bagi manusia (Majid, 2012: 47). Hablum minallāh menurut bahasa berarti hubungan dengan Allah. Namun dalam pengertian syariah makna hablum minallāh adalah "Perjanjian dari Allah, maksudnya adalah masuk Islam atau beriman dengan Islam sebagai jaminan keselamatan bagi manusia di dunia dan di akhirat". Sehingga dapat dipahami bahwa untuk membangun hubungan kepada Allah, manusia mempunyai kewajiban untuk menunaikan hak-hak Allah, dan apakah hak-hak Allah itu? Hak-hak Allah ialah mentauhidkan dan tidak menyekutukan-Nya dengan yang lain serta menjalankan syariat Allah. Misalnya: salat, puasa dan lainnya sebagai bentuk ibadah kepada Allah. Syahminan Zaini sebagaimana dikutip oleh Busri Endang (2010: 247) menyebutkan beberapa alasan mengapa manusia perlu beribadah, yaitu:

a. memenuhi tujuan Allah menciptakan manusia,

b. memenuhi janji manusia kepada Allah,

c. memberi makan kepada rohani,

d. jalan kebahagiaan di dunia,

e. jalan kebahagiaan di akhirat,

f. syarat memperoleh rahmat Allah. 
Sementara itu, jika manusia tidak mau menjaga hubungannya dengan Allah dalam arti lalai, tidak melaksanakan perintah dan mendekati larangan, maka hal demikian akan mengundang kemurkaan-Nya karena setiap yang dilakukan akan mendapat balasan. Sebagaimana Allah swt. berfirman dalam Q.S. Āli 'Imrān ayat 112 yang berbunyi:

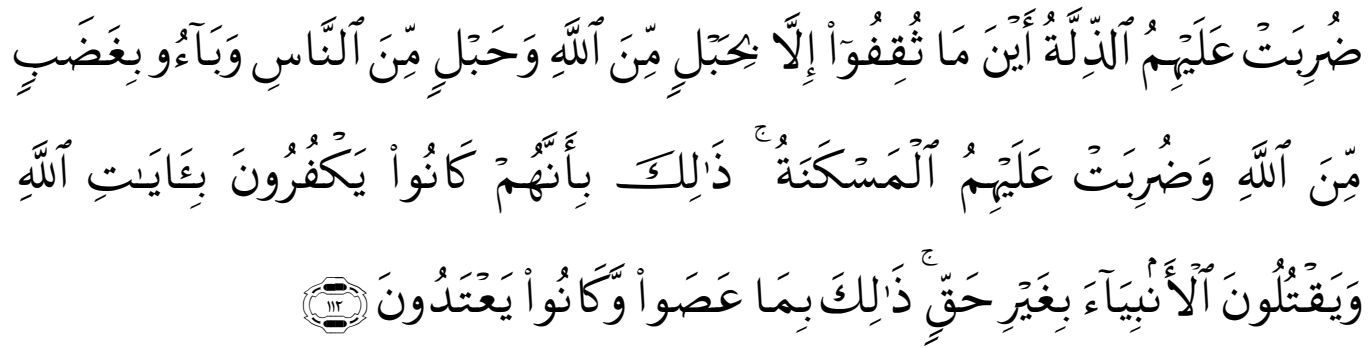

Artinya: "Mereka diliputi kehinaan di mana saja mereka berada, kecuali jika mereka berpegang kepada tali (agama) Allah dan tali (perjanjian) dengan manusia, dan mereka kembali mendapat kemurkaan dari Allah dan mereka diliputi kerendahan. Yang demikian itu karena mereka kafir kepada ayat-ayat Allah dan membunuh para Nabi tanpa alasan yang benar. Yang demikian itu disebabkan mereka durhaka dan melampaui batas".

Ayat ini memberikan implikasi tentang malapetaka yang telah menimpa Bani Israil sebagai akibat kedurhakaan mereka kepada Allah dan kepada para nabi. Sehingga mereka harus mengalami malapetaka, kehinaan, kemiskinan, dan kemurkaan dari Allah. Dan dalam ayat tersebut diberitakan pula bahwa jalan keluar dari segala malapetaka tersebut adalah membangun kembali hablum minallāh.

2. Hubungan manusia dengan sesama manusia (Hablum Minannās)

Manusia diciptakan Allah dalam struktur yang paling baik diantara makhluk Allah yang lain. Struktur manusia terdiri atas unsur jasmaniah (fisiologis) dan rohaniah (psikologis) serta telah dibekali dengan seperangkat kemampuan dasar yang memiliki kecenderungan untuk berkembang (Firman, 2017). Dengan adanya potensi tersebut, maka setiap manusia selain menjalin hubungan dengan Allah (hablum minallāh) juga harus menjalin hubungan dengan sesama manusia (hablum minannās). Kata hablum minannās terdiri dari tiga kata, yaitu hablun artinya hubungan atau ikatan, kata min artinya dari atau bisa mengandung pengertian dengan dan kata annās berarti manusia. Kemudian diartikan secara menyeluruh menjadi hubungan dengan manusia. Hubungan ini ditujukan antara manusia dan manusia lainnya (Endang, 2010).

Islam adalah $A d-D \overline{i n}$ yang sangat menganjurkan umatnya untuk membina hubungan yang baik antar sesama manusia sebagaimana firman Allah dalam Q.S. Al-Hujurāt ayat 13 yang berbunyi: 


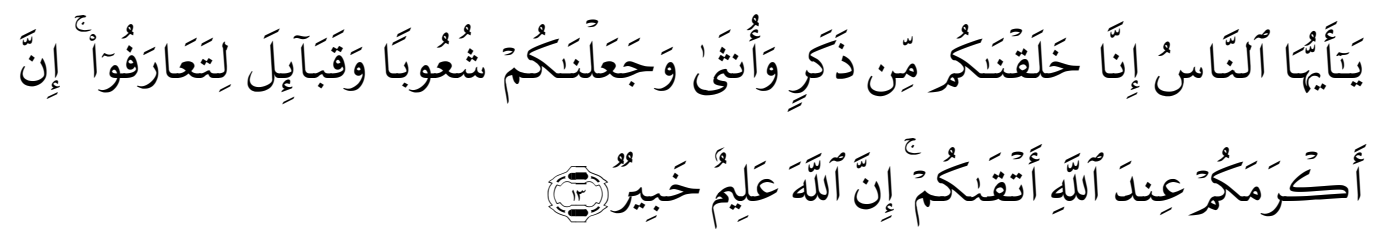

Artinya: "Hai manusia, sesungguh-nya kami menciptakan kamu dari seorang laki-laki dan perempuan, dan menjadikan kamu berbangsa-bangsa, dan bersuku-suku, supaya kamu saling mengenal, sesnugguhnya orang yang paling mulia di antara kamu di sisi Allah ialah orang yang paling bertakwa di antara kamu, sesungguhnya Allah Maha Mengetahui lagi Maha Mengenal".

Ayat ini menerangkan bahwa manusia adalah mahluk bio-sosial, dalam hidupnya manusia tidak dapat terlepas dari kehidupan bersama manusia yang lain. Manusia mempunyai kecenderungan untuk bergaul dan membaur dengan sesamanya. Naluri sebagai mahluk sosial ini menyebabkan manusia senantiasa bermasyarakat dalam kehidupan komunal. Dengan demikian, seorang muslim pada dasarya harus berusaha untuk dapat mengenal lingkungannya secara baik. Selain itu juga menjalin persahabatan dan persaudaraan kemanusiaan (ukhuwwah insāniyah) antar sesama. Hubungan persahabatan dan persaudaraan ditunjukan dalam muamalah dengan sesamanya, dan tidak merusak 'aqīdah yang dimilikinya.

3. Hubungan manusia dengan makhluk lainnya (Hablum Ma 'al Gairi)

Islam sebagai agama wahyu merupakan kerangka acuan paripurna untuk seluruh aspek kehidupan bagi setiap muslim. Pada dasarnya setiap muslim yang memiliki pemahaman terhadap Al-Quran dan Sunnah dengan tetap dan benar serta meyakini keduanya sebagai pedoman kehidupan, maka masyarakat akan tunduk pada kehendak Illahi, sehingga dapat diklasifiksikan tentang baik dan buruk, benar dan salah, boleh dan terlarang. Agama Islam pada hakikatnya bertujuan untuk membangun kehidupan manusia berdasarkan nilai-nilai kebajikan, dan membersihkannya dari berbagai kejahatan. Dalam hal ini, kebajikan mencakup segala hal yang diterima oleh nurani manusia sepanjang masa, sedang kejahatan menunjuk pada setiap hal yang selalu bertentangan dengan nurani manusia (Adnan, 2003).

Al-Quran dan Sunnah selalu meminta agar manusia mengisi hidupnya dengan bekerja untuk mempertahankan kehidupannya, yaitu dengan memanfaatkan apa yang telah Allah ciptakan baginya di muka bumi ini. Dalam pandangan Islam, hanya pekerjaan baik dan amal shaleh yang akan mendapatkan pahala. Hubungan manusia terhadap alam adalah sebagai pemanfaat, dan bukan sebagai saingan. Tidak seharusnya manusia mengeksploitasi alam sebagaimana firman Allah dalam Q.S. Al-Baqarah ayat 29 yang berbunyi: 


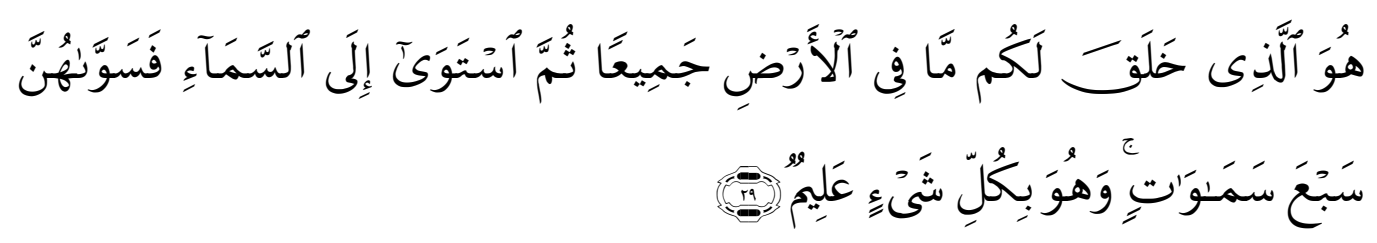

Artinya: "Dia-lah Allah, yang menjadikan segala yang ada di bumi untuk kamu dan Dia berkehendak (menciptakan) langit, lalu dijadikan-Nya tujuh langit. Dan Dia Maha mengetahui segala sesuatu".

Hubungan keduanya menurut ajaran Al-Quran maupun Sunnah merupakan hubungan yang dibingkai dengan aqidah, yakni konsep kemakhlukan yang sama-sama tunduk dan patuh kepada Al-Khaliq, yang diatur dan akhirnya semua kembali kepada-Nya. Dalam konsep kemakhlukan ini manusia memperoleh konsesi dari Yang Maha Penciptanya untuk memperlakukan alam sekitarnya dengan dua macam tujuan sebagaimana yang dituturkan oleh Al-Buraey (1986), yaitu:

a. al-intifă ${ }^{\prime}$ (pendayagunaan), baik dalam arti mengkonsumsi langsung maupun dalam arti memproduksi.

b. al-i'tibār (mengambil pelajaran) tehadap fenomena yang terjadi dari hubungan antara manusia dengan alam sekitarnya, maupun hubungan antara alam itu sendiri (ekosistem), baik yang berakibat konstruktif (iṣlāhn) maupun yang berakibat destruktif (ifs $\bar{a} d)$.

Dalam sejarah Islam, pada waktu terjadi pembebasan kota Makkah (Fathu Makkah), kekhawatiran akan terjadinya tindakan-tindakan yang merusak lingkungan alam di tanah haram itu dengan cepat diantisipasi oleh Nabi saw. Beliau melarang perburuan binatang dan mencabuti rerumputan di tanah haram. Kebijakan ini sangat relevan dengan kondisi alam di tanah haram yang miskin lingkungan nabati dan hewani. Bahkan sampai sekarangpun perlindugan flora dan fauna di sana masih terus berlaku, dan dikaitkan dengan prinsip ibadah haji atau umrah. Seandainya tidak ada perlindungan terhadap kehidupan flora dan fauna di tanah haram sebagai pusat kegiatan haji atau umrah, kemudian ketika umat muslim melaksanakan ibadah haji mengambil atau memotong tanaman di sana dengan dalih untuk souvenir atau obat, kemungkinan dalam satu musim haji saja sudah cukup untuk merusak lingkungan alam, khususnya lingkungan hidup flora dan fauna juga manusia di sana yang tidak dikehendaki oleh Islam (Anis, 2005).

\section{Materi Pendidikan Agama Islam dalam Ranah Grounded Theory}

Grounded theory pada awalnya dikembangkan pada tahun 1960-an oleh ahli sosiologi yang bernama Barney Glaser dan Anselm Strauss melalui hasil riset dengan topik "Discovery of Grounded Theory", diterbikan pada tahun 1967. Strauss cenderung untuk berkonsentrasi dalam menentukan prosedur dalam 
mengaplikasikan pendekatan, sedangkan Glaser menentang perubahan apapun dari gagasan awalnya. Dua versi grounded theory kemudian muncul, yaitu Straussian dan Glaserian. Dalam kajian-kajian yang berkaitan dengan komunikasi dan manajemen, pendekatan Straussian lebih populer, walaupun kedua format Glaserian dan Straussian terus berubah perlahan-lahan dari tahun ke tahun seiring dengan banyaknya peneliti yang menggunakan pendekatan tersebut (Glaser, 1967).

Noeng Muhadjir (2002) mengatakan bahwa kualitas kebenaran sebuah teori hasil dari grounded theory terkait langsung dengan kualitas prosedur kerja dalam mencari kebenaran (epistemologi). Dengan prosedur kerja yang baik, kualitas kebenaran yang diperoleh pun terbatas pada kebenaran epistemologik dalam wujud kebenaran tesis dan lebih jauh menjadi kebenaran teori. Kebenaran tesis dan kebenaran teori pada gilirannya akan disanggah oleh tesis atau teori lain sebagai proses berkesinambungan dari ilmu pengetahuan dalam memperoleh kebenaran epistemologik. Dasar filosofis dari grounded theory adalah interaksi simbolik. Interaksi simbolik sendiri berasal dari psikologi sosial. Interaksi yang dilakukan oleh manusia selalu bergantung pada lingkungannya. Sehingga asumsi ini mendorong untuk melihat secara jeli pemahaman terhadap tindakan atau perilaku seseorang, karena setiap tindakan manusia selalu memiliki arti tertentu (Muhadjir 2002).

Oleh karena itu, grounded theory dikembangkan berdasarkan middle theory yang telah dipaparkan pada poin sebelumnya. Karena fokus pembahasan ini pada kerangka teori sosial, maka middle theory yang dikembangkan menjadi grounded theory dibatasi pada dua poin, yaitu hubungan manusia dengan manusia (hablum minannās) dan hubungan manusia dengan makhluk lainnya (hablum ma'al gairi). Grounded theory sebagai paradigma keilmuan multidisipliner dari dua poin ini meliputi sifat-sifat atau akhlāk terpuji (mạ̣mūdah) dan sifat-sifat atau akhlāk tercela (mażmumah).

1. Sifat-sifat terpuji (Maḥmūdah)

Akhlāk terpuji merupakan segala macam sikap dan tingkah laku yang baik (terpuji) (Mustofa, 2010). Sedangkan berakhlāk terpuji adalah menghilangkan semua adat kebiasaan yang tercela dan sudah digariskan oleh agama Islam serta menjauhkan diri dari perbuatan tersebut (Asmaran, 1994). Hal ini juga disampaikan oleh Amin (2016) bahwa akhlāk maḥmūdah diartikan sebagai perilaku baik manusia dan disenangi oleh individu maupun sosial, serta sesuai dengan ajaran yang bersumber dari Tuhan. Perilaku baik ini dilahirkan oleh sifat-sifat mahmmūdah yang terpendam dalam jiwa manusia. Allah berfirman dalam Q.S. Al-Qalam ayat 4 yang berbunyi: 


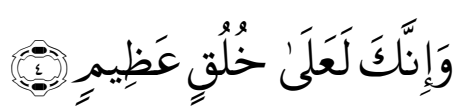

Artinya: "Dan sesungguhnya kamu benar-benar berbudi pekerti yang agung".

Oleh karena itu, sikap dan tingkah laku yang lahir adalah cermin dari sifat atau kelakuan batin seseorang. Akhlāk yang terpuji senantiasa berada dalam kontrol Ilahiyah yang dapat membawa nilai-nilai positif dan kondusif bagi kemaslahatan umat, seperti sabar, jujur, ikhlas, bersyukur, tawādhu' (rendah hati), husnudzan (berprasangka baik), optimis, suka menolong orang lain, suka bekerja keras dan lain-lain (Aminuddin, 2005). Selain itu, adapun hal-hal yang perlu dibiasakan sebagai akhlāk yang terpuji dalam Islam menurut Syarifah Habibah (2015), antara lain:

a. berani dalam kebaikan, berkata benar serta menciptakan manfaat, baik bagi diri maupun orang lain,

b. adil dalam memutuskan hukum tanpa membedakan kedudukan, status sosial ekonomi, maupun kekerabatan,

c. arif dan bijaksana dalam mengambil keputusan,

d. pemurah dan suka menafkahkan rezeki baik ketika lapang maupun sempit,

e. ikhlas dalam beramal semata-mata demi meraih ridha Allah,

f. cepat bertobat kepada Allah ketika berdosa,

g. jujur dan amanah,

h. tidak berkeluh kesah dalam menghadapi masalah hidup,

i. penuh kasih sayang,

j. lapang hati dan tidak balas dendam,

k. malu melakukan perbuatan yang tidak baik,

1. rela berkorban untuk kepentingan umat dan dalam membela agama Allah.

2. Sifat-sifat tercela (Mażmumah)

Imam Al-Ghazali mengatakan bahwa akhlāk tercela (muhlikāt) merupakan segala tingkah laku manusia yang dapat membawanya kepada kebinasaan dan kehancuran diri yang tentu saja bertentangan dengan fitrahnya untuk selalu mengarah kepada kebaikan. Al-Ghazali dalam Asmaran (1994) menerangkan akal yang mendorong manusia melakukan perbuatan tercela (maksiat), diantaranya yaitu:

a. dunia dan isinya, yaitu berbagai hal yang bersifat material (harta, keududukan) yang ingin dimiliki manusia sebagai kebutuhan dalam melangsungkan hidupnya agar bahagia,

b. manusia, selain mendatangkan kebaikan, manusia juga dapat mengakibatkan keburukan,

c. setan (iblis), merupakan musuh yang paling nyata, ia menggoda manusia melalui batinnya untuk berbuat jahat dan menjauhi Tuhan, 
d. nafsu, adakalanya baik dan adakalanya buruk, akan tetapi nafsu cenderung mengarah kepada keburukan,

Pada prinsipnya, faktor-faktor yang mempengaruhi pembentukan akhlāk ditentukan oleh dua faktor, yaitu faktor internal dan eksternal.

a. Faktor internal

Faktor internal merupakan keadaaan diri sendiri yang meliputi latar belakang pemahaman terhadap ajaran agama, kecerdasan, motivasi, minat, sikap, bakat, konsep diri dan kemandirian. Pengetahuan agama seseorang akan mempengaruhi pembentukan akhlāk, karena dalam pergaulan sehari-hari tidak akan dapat terlepas dari ajaran agama. Selain itu, seseorang juga harus memiliki konsep diri yang matang. Sebagaimana dijelaskan oleh Muntholi'ah (2002) bahwa konsep diri dapat diartikan sebagai gambaran mental seorang terhadap dirinya sendiri, pandangan terhadap diri, penilaian terhadap diri, serta usaha untuk menyempunakan dan mempertahankan diri.

Seseorang tidak akan mudah terpengaruh dengan pergaulan bebas, mampu membedakan antara yang baik dan buruk, benar dan salah dengan adanya konsep diri yang baik. Selain itu, faktor internal juga dipengaruhi oleh minat, motivasi dan kemandirian belajar. Minat adalah suatu harapan, dorongan untuk mencapai sesuatu atau membebaskan diri dari suatu perangsang yang tidak menyenangkan. Menurut Mujib (2006) bahwa motivasi adalah menciptakan kondisi yang sedemikian rupa, sehingga anak mau melakukan apa yang dapat dilakukannya.

b. Faktor eksternal

Faktor eksternal adalah pengaruh yang berasal dari luar diri seseorang, seperti pendidikan keluarga, sekolah dan lingkungan masyarakat. Selama ini dikenal adanya tiga lingkungan pendidikan, yaitu lingkungan keluarga, sekolah, dan masyarakat. Menurut Abuddin Nata sebagaimana dikutip oleh Iwan (2016) bahwa faktor yang berpengaruh terhadap pembentukan perilaku atau akhlāk seseorang sangat dipengaruhi faktor lingkungan.

1) Lingkungan keluarga (orang tua)

Orang tua merupakan penanggung jawab pertama dan yang utama terhadap pembinaan akhlāk dan kepribadian seorang anak. Orang tua dapat membina dan membentuk akhlāk dan kepribadian anak melalui sikap dan cara hidup yang diberikan orang tua yang secara tidak langsung merupakan pendidikan bagi sang anak. Dalam hal ini perhatian yang cukup dan kasih sayang dari orang tua tidak dapat dipisahkan dari upaya membentuk akhlāk dan kepribadian seseorang. 
2) Lingkungan sekolah (pendidik)

Pendidik di lingkungan sekolah mempunyai andil yang cukup besar dalam upaya pembinaan akhlāk dan kepribadian anak, yaitu; melalui pembinaan dan pembelajaran pendidikan agama Islam kepada siswa. Pendidik harus dapat memperbaiki akhlāk dan kepribadian siswa yang sudah terlanjur rusak dalam keluarga, selain juga memberikan pembinaan kepadanya. Disamping itu, kepribadian, sikap dan cara hidup, bahkan sampai cara berpakaian, cara bergaul dan berbicara oleh seorang pendidik juga mempunyai hubungan signifikan dengan proses pendidikan dan pembinaan moralitas siswa yang sedang berlangsung.

3) Lingkungan masyarakat (lingkungan sosial)

Lingkungan masyarakat tidak dapat diabaikan dalam upaya membentuk dan membina akhlāk serta kepribadian seseorang. Seorang anak yang tinggal dalam lingkungan yang baik, maka ia juga akan tumbuh menjadi individu yang baik. Sebaliknya, apabila orang tersebut tinggal dalam lingkungan yang rusak akhlāknya, maka tentunya juga akan ikut terpengaruh dengan hal-hal yang kurang baik pula. Lingkungan pertama dan utama pembentukan dan pendidikan akhlāk adalah keluarga yang mengajarkan kepada anak pengetahuan tentang Allah, pengalaman tentang pergaulan manusia dan kewajiban mengembangkan tanggung jawab terhadap diri sendiri dan terhadap orang lain. Tetapi lingkungan sekolah dan masyarakat juga ikut andil dan berpengaruh dalam terciptanya akhlāk mulia bagi seseorang.

\section{SIMPULAN}

Berdasarkan pembahasan pada poin-poin sebelumnya, dapat dipahami bahwa mengembangkan materi pendidikan agama Islam dalam kerangka teori sosial sebagai paradigma keilmuan multidisipliner mencakup tiga aspek, yaitu grand theory, middle theory dan grounded theory. Membicarakan pendidikan agama Islam dalam ranah grand theory, maka yang menjadi kajiannya adalah 'Aqīdah, Akhlāk, Al-Quran-Hadis, Fiqh dan Tarikh. Sementara itu, membicarakan pendidikan agama Islam dalam ranah middle theory, maka kajian yang dikembangkan mencakup lima grand theory tersebut, seperti grand theory Akhlāk dengan middle theory-nya adalah hablum minallāh, hablum minannās dan hablum ma'al gairi. Sedangkan, jika membicarakan Pendidikan Agama Islam dalam ranah grounded theory, maka kajian yang dikembangkan didasarkan kepada grand dan middle tehory, yaitu akhlāk maḥmūdah dan mażmumah. Selain itu, multidisipliner dalam materi pendidikan agama Islam itu sendiri maupun keilmuan lain menunjukkan adanya keterpaduan/keintegralan antara pelajaran yang satu dengan pelajaran yang lain. 


\section{DAFTAR PUSTAKA}

Adnan. 2003. Islam Sosialis; Pemikiran Sistem Ekonomi Sosialis Religius Sjafruddin Prawira Negara, Yogyakarta: Menara Kudus.

Al Buraey, Muhammad. 1986. Islam: Landasan Alternatif Administrasi Pembangunan, Terj. Ach. Nashir Budiman, Jakarta: CV Rajawali.

Amin, Samsul Munir. 2016. Ilmu Akhlāk, Jakarta: Amzah.

Aminuddin, dkk. 2005. Pendidikan Agama Islam untuk Perguruan Tinggi, Bogor: Ghalia Indonesia.

Anis, Afif Najih. 2005. Islam dalam Perspektif Sosio Kultural, Jakarta: Lantabora Press.

Asmaran. 1994. Pengantar Studi Akhlāk, Jakarta: RajaGrafindo Persada

Assegaf, Abd. Rachman. 2019. Ilmu Pendidikan Islam; Mazhab Multidisipliner, Depok: Rajawali Pers.

Departemen Agama RI. 2008. Al-Hikmah; Al-Quran dan Terjemahannya, Bandung: Diponegoro.

Endang, Busri. 2010. "Futurologi Dan Phenomenologi Nilai Spiritual (Hubungan Allah, Manusia, Dan Alam)", dalam Visi Ilmu Pendidikan, Vol. 2, No. 1.

Firman, Arham Junaidi. 2017. "Paradigma Hasan Langgulung tentang Konsep Fitrah dalam Pendidikan Islam", dalam UHAMKA: Jurnal Pendidikan Islam, Vol. 8, No. 2.

Glaser, B.G. \& Strauss, A.L. 1967. The Discovery of Grounded Theory, New York: Aldine Publishing Co.

H.P., Mc Kenna. 1997. Nursing Models and Theories, London: Routledge.

Habibah, Syarifah. 2015. "Akhlāk dan Etika dalam Islam", dalam Jurnal Pesona Dasar, Vol. 1 No. 4.

Iwan. 2016. "Pendidikan Akhlāk Terpuji Mempersiapkan Generasi Muda Bekarakter", dalam Jurnal Al-Tarbawi Al-Haditsah, Vol. 1, No. 1.

Mahmudi. 2019. "Pendidikan Agama Islam dan Pendidikan Islam Tinjauan Epistemologi, Isi dan Materi”, dalam Ta'dibuna: Jurnal Pendidikan Agama Islam, Vol. 2, No. 1.

Majid, Abdul. 2005. Perencanaan Pembelajaran, Bandung : Remaja Rosdakarya.

Majid, Abdul. 2012. Belajar dan Pembelajaran Pendidikan Agama Islam. Bandung: Remaja Rosdakarya.

Mujib, Abdul. 2006. Ilmu Pendidikan Islam, Jakarta: Kencana.

Mas'ud, Abdurrahman. 2002. Menggagas Format Pendidikan Nondikotomik; Humanisme Relegius Sebagai Paradigma Pendidikan Islam, Yogyakarta: Gama Media.

Muhadjir, Noeng. 2002. Metode Penelitian Kualitatif, Yogyakarta: Rake Sarasin. 
Muntholi'ah. 2002. Konsep Diri Positif Penunjang Prestasi PAI, Semarang: Kerja sama Penerbit Mangkang Indah dan Yayasan Al-Qalam.

Mustofa, A. 2010. Akhlāk Tasawuf, Bandung: Pustaka Setia.

Peraturan Menteri Agama RI No. 000912 Tahun 2013 tentang Kurikulum Madrasah 2013 Mata Pelajaran Pendidikan Agama Islam dan Bahasa Arab BAB III Standar Isi Pendidikan Agama Islam dan Bahasa Arab di Madrasah.

Rohmatika, Ratu Vina. 2019. "Pendekatan Interdisipliner dan Multidisipliner dalam Studi Islam”, dalam Al-Adyan, Vol. 14, No. 1.

Samidi. 2016. "Tuhan, Manusia dan Alam: Analisis Kitab Primbon Atassadhur Adammakna", dalam Shahih, Vol. 1, No. 1.

Smith, Mary Jane \& Patricia R. Liehr. 2008. Middle Range Theory for Nursing, New York: Springer Publishing Company.

Subadi, Tjipto. 2009. Sosiologi dan Sosiologi Pendidikan: Suatu Kajian Boro dari Perspektif Sosiologis Fenomenologis, Surakarta: UMS Publish.

Tabrani. 2014. "Islamic Studies dalam Pendekatan Multidisipliner (Suatu Kajian Gradual Menuju Paradigma Global)", dalam Jurnal Ilmiah Peuradeun; International Multidisciplinary Journal, Vol. II, No. 02.

Tholkhah, Imam dan Ahmad Barizi. 2004. Membuka Jendela Pendidikan; Mengurai Benang Tradisi dan Integrasi Keilmuan Pendidikan Islam, Jakarta: PT. Raja Grafindo Persada. 